\title{
Rebel reviewers: Social media review pages as sites of Confederate memorial discourses by Laura March
}

\begin{abstract}
Online review platforms - such as Facebook Pages, Yelp, and Google Reviews - host millions of user-generated posts. Some reviewers choose to use these platforms to share political opinions and calls for activism. One example of this phenomenon, UNC-Chapel Hill's "Silent Sam" Confederate statue review page on Facebook, provides an opportunity to examine comments from users asserting their pro-statue and anti-statue opinions. While protestors removed the statue in August 2018, its unofficial page (and its posts) remains visible online and continues to garner new "reviews" after the monument's physical removal. This study analyzes the engagement publicly visible on Silent Sam's Facebook reviews. Despite the large volume of research on social network sites, the author is unaware of any studies of activist posts on online review spaces. Discovering the most prevalent claims made in pro-Confederate posts will help educators, activists, online moderators, and creators of Terms of Service agreements determine where they can (and should) respond to racist rhetoric.
\end{abstract}

\section{Contents}

$\underline{\text { Introduction }}$

Rationale, aim, and research questions

Background

Data and methods

$\underline{\text { Results }}$

Discussion and conclusion

\section{Introduction}

Online review platforms - such as Facebook Pages, Yelp, and Google Reviews - host millions of user-generated posts. Some reviewers choose to use these platforms to share political opinions and calls for activism. One example of this phenomenon, UNC-Chapel Hill's "Silent Sam" Confederate statue review page on Facebook (Silent Sam, ca. 2015), provides an opportunity to examine comments from users asserting their pro-statue and anti-statue opinions.

While protestors removed the statue in August 2018, its unofficial page (and its posts) remains visible online as of late 2020 and continues to garner new "reviews" after the monument's physical removal. This study analyzes the engagement publicly visible on Silent Sam's Facebook reviews. Despite the large volume of research on social network sites, the author is unaware of any studies that have been conducted of activist posts on online review spaces.

\section{Rationale, aim, and research questions}

Social network sites impact the creation, management, and preservation of digital content. This research examines one facet of social media platforms, online user-created reviews, as related to political engagement and activism.

More than 1,700 Confederate memorials (monuments, place names, and other symbols) remain in public spaces (Southern Poverty Law Center [SPLC], 2019). These shrines function as state-sanctioned celebrations of Confederate lore with deep roots in racism and violence [1]. People who support the continued display of Confederate memorials often employ coded language in their arguments for preserving and learning history, including phrases such as "it's heritage, not hate" [2] . Yet prior work indicates that knowledge of Southern history negatively correlates with support for public displays of Confederate symbolism (Strother, et al., 2017). Examining these discussions in situ will provide further insights into the discourses (i.e., structures of meaning and interaction) visible in the review posts. Discovering the most prevalent claims made in pro-Confederate posts will help educators, activists, online moderators, and creators of Terms of Service agreements determine where they can (and should) respond to racist rhetoric.

Additionally, debates over Confederate symbolism may be the first foray into local activism for many people [3] . This, coupled with the low barriers of social media use, offers new possibilities for anti-racist work. Preparing activists to effectively respond to coded racism in different online environments is particularly important considering new research on the links between social media and hate crimes (Müller and Schwarz, 2018; 2017). 
Parallel to Cotter's (2017) call to move and contextualize the Silent Sam statue, analyzing the related review posts and the users who create them will allow us - and future scholars - to see the effects of White supremacy and its impact on digital lives. By embedding this study within the historical constructs of Confederate memorialization, this paper responds to calls for research on anti-racist work that does not rely on tokenism (Hudson, 2017) and further analysis of targeted phrases used by White nationalists in online contexts [4]. More generally, this research investigates how people engage in different uses of social media [ $]$ ].

\section{Research questions}

- RQ1: Which reviews (negative or positive) are associated with different types of engagement ("likes" and replies)? -RQIa: Does the proportion of the original posts, replies, and "likes" reflect recent polling data on the removal of Confederate monuments?

$-R Q 1 b$ : Are there gender-based patterns similar to prior research on social media use and/or feelings towards Confederate symbols?

- RQ2: Which speech acts (Herring, et al., 2005) do reviewers use and does this differ between negative and positive reviews?

- RQ3: How often, what types, and when do reviewers use coded language or "commonsense" racism (Hughey and Daniels, 2013) and how does this align with the "heritage versus hate" claims identified by the SPLC (2019)?

\section{Background}

Contextual information on Confederate memorials in America, online engagement and interaction, and user-created reviews provides the necessary framework in which to examine this new phenomenon.

\section{Confederate memorials}

Dylann Roof's 2015 murder of nine Black people attending church in Charleston, S.C. constituted a turning point in contemporary efforts to remove Confederate symbols on public grounds. Photographs of Roof, a White supremacist, holding a Confederate battle flag emerged shortly after the massacre (SPLC, 2016). Appeals to move Confederate monuments included one by City Council members in Charlottesville, Va., who voted to remove a statue of Robert E. Lee from a public park in 2017 []ㅡ. This decision was met with demonstrations by White nationalists, resulting in the death of Heather Heyer, a counter-protester [7]. Many White Southerners hold the refuted notion that the Confederacy was an attempt to defend the region's honor unrelated to slavery and/or White supremacy []. This directly contradicts primary resources from the time, such as Confederate Vice President Stephen's Cornerstone Speech: "Our new government is founded upon ... the great truth that the negro is not equal to the white man; that slavery subordination to the superior race is his natural and normal condition" (Stephens, 1861). Rallies for both the preservation and removal of Confederate monuments have increased across America since 2015, including many at the Silent Sam monument on the UNC Chapel Hill campus in North Carolina (SPLC, 2019; Long, 2018; AP News, 2019).

Case selection. Silent Sam. Silent Sam typifies Confederate statues in the American South in many respects. It was built during the largest construction period of Confederate memorials (1900-1920), which coincided with the codification of Jim Crow laws and the revival of the Ku Klux Klan (SPLC, 2019). The United Daughters of the Confederacy erected more than 700 Confederate memorials (many more than any other group) and sponsored one third of the funds required for Silent Sam (Galuszka, 2017; UNC Archives, 2018). Like other Confederate memorials, the statue serves as a lightning rod of social conflict during times of crisis [9]. It was a site of graffiti after the assassination of Martin Luther King Jr. in 1968 and student marches during the L.A. riots of 1992 (UNC Archives, 2018). More recently, Alamance and Orange County pro-Confederate groups organized a rally at Silent Sam in October 2015 (Bonner, 2015) and January 2019 (AP News, 2019) - one of 350 similar rallies that took place across the country in the six months after the Charleston massacre (SPLC, 2019).

The statue is an example of Confederate memorials' insidious historical purpose - on the surface, it appears to honor reluctant yet valiant soldiers, while documentation of its dedication ceremony exposes its original objective as a physical reminder of racist violence [10]. Silent Sam's dedication ceremony, like many other Confederate memorial celebrations, was used to cement the statue's relationship to White supremacy. The University and community leaders who erected Silent Sam explained that the memorial was not simply "a monument to the dead," but also "a lesson for the living," in which White manhood includes horse-whipping a Black woman after she "insulted ... a [White] Southern lady" [11].

Silent Sam is atypical in one aspect - protestors pulled the statue down from its base on 20 August 2018 (UNC Archives, 2018; Long, 2018). Yet the debate over the statue's reinstatement continues as of this writing (Stancill, 2019; McGee, 2019). Related arguments, made before and after the statue's removal, remain visible on social media, including on Silent Sam's unofficial Facebook page reviews. Pro-Confederate memorial user-created content is so pervasive and similar that the SPLC (2019) created a list of common claims used to defend Confederate memorials in public spaces. This research examines whether users expressing positive reviews for Silent Sam use these claims and which are

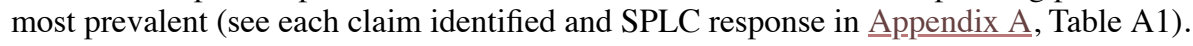

\section{Online engagement and interaction}

Online social networks pique interest and promote the communication of information through engagement and interaction. User engagement is sustained interest in content (regardless of whether that interest is shared with others), while interactivity is communication between individuals [12]. Montalvo defines social media by its ability to turn Internet-based communications into interactive dialogues [13]. Online social network sites depend on users investing their time, attention, and emotions; as such, engaging experiences are essential [14].

Engagement with social media is fueled by user-created and user-generated content. User-created content refers to works that have been published, contain creative effort, and are usually made outside of professional routines and practices [15]. User-generated content encompasses both the production of new content and the sharing of content made by others [16]. Motivating factors for creating and/or sharing content include "connecting with peers, achieving fame, notoriety or prestige, and expressing oneself" [17]. Users posting reviews of contested spaces may be inspired by any, or all, of these motivations. 
Instead of positioning user-generated content as a private activity, social media posts can be interpreted as outward-facing signals. The importance of these signals is illustrated by Ellison and boyd's (2013) shift in focus of their definition of online social network sites from profile creation (boyd and Ellison, 2007) to streams of activity. This mirrors Good's (2012) view of user-generated content as social texts. Users express their individuality on social media through published actions, membership in groups, and/or repositories of user-generated content [18].

Online activism. Social media facilitates activism by harnessing the power of collective action quickly, inexpensively, and efficiently. Whether activist movements take place online, off-line, or include a combination of both approaches, organizers must find a way to translate supporters' sympathetic attitudes into overt behaviors. Hinkle, et al. (1996) found that one's identification with other members in an organization combined with the perceived efficacy of that organization's tactics impact a person's predilection for activism. Online connections can facilitate both of these aspects - allowing users to share their involvement with an activist group as well as describe their effectiveness. While it is people not technologies - that accomplish revolutions [19], social media offers the possibility of reaching millions of potential activists at the same time who are not in the same physical space or may not know one another [20].

Online social networks have, of course, facilitated many off-line activist events. Facebook and Twitter were used to organize peace marches in Columbia (Neumayer and Raffl, 2008), launch election and government protests in Iran (Amin, 2010), initiate demonstrations against the Guatemalan president (Harlow, 2012), and spread information on "Arab Spring" uprisings (Tufekci and Wilson, 2012; Jones, 2012; Tufekci, 2017). In the United States, social media was instrumental in mobilizing events such as Occupy Wall Street, the Women's March, the March for Science, and the March for Our Lives (Yammine, et al., 2018; Fisher, et al., 2017; Ley and Brewer, 2018). Online social networks offer activists the ability to spread information and connect with like-minded audiences quickly and efficiently [21]. While most problems cannot be solved solely through "likes," Facebook provides an easy entry into volunteerism and activism [22]. Activists who use social media can showcase collective participation by alerting a user's network to the actions a friend has taken [23]. Users not specifically connected with activists may come across review-based activist and/or political posts as part of geolocation queries connected with Facebook page reviews and check-ins.

Political engagement. Social media creates "opportunities for civic and political engagement" [24]. Use of a social network site is associated with increased rates of political participation off-line (Gil de Zúñiga, et al., 2012; Tufekci and Wilson, 2012). More specifically, using online social networks as a source of news has a direct effect on off-line political participation, while using social media for social interaction has an indirect effect via online political expression (Gil de Zúñiga, et al., 2014). Using Pew Research Center survey data, Bode (2017) found that even people uninterested in politics engaged in "easy" political behavior ("liking" and commenting) on political social media posts and that this engagement is associated with greater off-line political activity.

Political disagreement and engagement. Online social network users "perceive higher levels of political disagreement than non-users, and they perceive that difference on social media more than they do elsewhere" [25]. Research on the effectiveness of political persuasion online is mixed. On one side, Facebook users are more likely to be exposed to - and spread more information from - distant contacts rather than close friends (Bakshy, 2012). Higher levels of participation in online discussions that cut-across political disagreements indirectly leads to increased off-line political participation through the sharing of information and its positive feedback [26]. On the other, algorithms can create "bubbles" where users are only presented with content similar to that which they have previously engaged with - and this can drive political polarization and enable extremism (Sunstein, 2017).

While scholars have found that progressive users were more likely to engage in crossideological political communication than conservative users (Boutyline and Willer, 2016; Barberá, et al., 2015), Barberá, et al. also "conclude that previous work may have overestimated the degree of ideological segregation in social-media usage" [27]. Similarly, a study of Spanish politicians, media journalists, and Twitter users found that only a small number of users participating in online political discussion changed their behavior as a result of their involvement (Guerrero-Solé, 2018). Moreover, only members in one of the four political groups studied (Podemos, a leftist party) showed significantly greater ratios of engagement with users that did not share their political views [28] . Agur and Frisch's (2019) study of Hong Kong's Umbrella Movement found that the student political activists were unable to persuade others to join their cause, which was not surprising given polarization of Internet discourse related to their movement [29]. Recent findings on "echo chambers" reveals "the popular saying that 'haters gonna hate' and 'lovers gonna love,' regardless of which media they rely on the most, is a more accurate description" of political expression in online social networks (Nguyen and Tien $\mathrm{Vu}, 2019$ ).

Anger and hate speech. In a Norwegian survey of self-reported social media use, angry people are more likely to debate "with people having both similar and opposing views" and "vseek out information confirming their views more frequently" [잉. More disturbingly, President Trump's use of Twitter to post angry and racist rhetoric related to Islamic-related topics is highly correlated with anti-Muslim hate crimes (Müller and Schwarz, 2018). On Facebook, "right-wing anti-refugee sentiment on Facebook predicts violent crimes against refugees in otherwise similar municipalities with higher social media usage" [31]. Trump - and White nationalist groups - use racialized othering to frame and stoke fears in order to "silence, breed division, and engage in fearmongering" [32]. As Trump is celebrated for his "politically incorrect" stance, individual social media users may also reasonably expect to be celebrated for angry and racist posts [33].

Anger can be expressed in online political posts through flaming. Hutchens, et al. (2015) neatly summarizes the definition of flaming as "the interpretation and sending of aggressive or hostile messages across various forms of online communication" [34]. This differs from Herring's (1993) interpretation of adversarial behavior on academic lists, which is characterized by posts that include "evidence of careful planning and preparation" [35]. People's intention to flame increases when they engage in online political discussions, have less political knowledge, and view flaming as acceptable [36].

Demographic information on social media. Online social networks control the display of demographic information on their platform by the choices they allow users to select. For example, new users must select between "male" or "female" on the first sign-up page on Facebook (Facebook, n.d.-a). If new users do not select between the two options, a popup with the text "Please choose a gender. You can change who can see this later" appears before signup is allowed to continue - see screenshot in Appendix B, Figure B1 (Facebook n.d.-a). Furthermore, users are only able to customize their gender options after the sign-up process within the "About" portion of their profile. In Cirucci's (2017) focus group study of 45 college aged participants, just half of the Facebook users were familiar with additional gender options available and only one changed her gender display (from female to cisfemale) [37]. Gender also influences which content is automatically presented, including targeted advertising [38]. One's selected gender presents itself immediately to other users, as Facebook presents the publicly viewable statement "If you know <username $>$, send $<$ him/her/them $>$ a message" with respective pronouns offered at the top of every non-connected profile page and About page. 
In contrast, new users are not required to select race or ethnic categories to sign up for Facebook accounts, nor are these selections visible to outside viewers unless the user chooses to make that information publicly available. This lack of options regarding race and ethnicity provides further insight into Facebook designer and programmer assumptions, where explicit racial and ethnic categories are deemed inessential [39]. Facebook's Non-Discrimination Policy states, "Ads must not discriminate against people based on personal attributes such as race, ethnicity, color, national origin, religion, age, sex, sexual orientation, gender identity, family status, disability, medical or genetic condition" (Facebook, n.d.-b). However, proxies for racial and/or ethnic categories are still easily employable as of June 2019 , as advertisers are able to target their content to users interested in categories such as "Latino" (ㄹppendix B, Figure B2), "Asian American Culture" (ㅅppendix B, Figure B3), and "African-American Culture" (Appendix B, Figure B3) (Facebook, n.d.-c; n.d.-d; n.d.-e).

Gender differences in online engagement. Gender differences in online communication is well-documented. Thirteen years before Mark Zuckerberg founded Facebook in his Harvard dorm room, Selfe and Meyer (1991) found that men and other people who enjoy off-line social privilege dominated online academic conversations at a virtual asynchronous conference. Around the same time, Herring (1993; 1992) established that while men and women both respond negatively to aggressive online discourse, women produced less adversarial content, dropped out of conversations more frequently, and were more actively censored by men who ignored or delegitimized their messages.

Despite these challenges, women have surpassed men in their frequency of use and preference for technology-mediated communication, which includes social media along with text messaging and video chat [40]. There is a higher percentage of women (74 percent) who use at least one online social network than men (62 percent) in the United States (Pew Research Center, 2019). More specifically, 52 percent of all American women use Facebook, compared to 48 percent of American men as of January 2018 (Statista, n.d.).

Differences in the way social media are used by men and women have also been established. Men reported a higher rate of using online social networks for forming new relationships and gaining general information while women reported higher rates of using them for relationship maintenance (Muscanell and Guadagno, 2012; Krasnova, et al., 2017). Speech acts provide another area of variance. In a study of teenagers in an online chat room, men used more manipulative speech acts while women performed more reactive acts that tended to contribute more to information exchange [ $\underline{41}]$.

Personality differences provide another disparity - while both male and female social media users are more likely to be extraverted, only men with greater degrees of emotional instability were found to be more frequent users [42]. Correa, et al. (2010) posit that men with emotional instability use social media to bolster self-esteem by reaching out to others [43]. Moreover, a study of demographics on Reddit engagement found that while women are equally as likely to vote on and read posts as men, they contributed fewer news stories and commented less on posts [44]. More active forms of engagement, i.e., posting and commenting, "may be perceived as riskier for women and therefore undesirable" [45], echoing Herring's (1993) 26-year-old findings that a minority of male participants tend to dominate online discussions through the sheer number of posts created as well as rhetorical intimidation tactics [46]. In terms of online political engagement, men are more likely than women to post original political content, while women are slightly more likely to unfriend other users for political reasons and engage in less visible political behaviors such as commenting or liking original posts created by others [47].

Limitations of gendered demographic information. By forcing users to choose between binary gender options, Facebook designers and programmers make "decisions that render gender into a category [that] recursively influence[s] how we identify ourselves and others" [48]. While this study identifies and analyses gender by collecting user-chosen pronouns, the researcher does not condone exclusive binary gender expression and would include non-binary options if they were displayed on the user accounts studied.

Limitations of digital activism and online engagement. Social media function within existing political and institutional contexts [49]. Organizers and activists are limited by their specific historical and social contexts and must choose from available tactics [50]. Governments censor social network sites as well as use them to collect personal information and trap activists into spreading false protest announcements [51]. Restrictions to Internet access, as well as maintaining the time and skills required to participate in digital activism, often limit participation to the wealthy and elite [드.

One major difficulty of researching social media is the misinterpretation of expressions [53]. Content produced with specific meanings for a particular audience can be misunderstood when viewed with a different set of assumptions [54]. This is important to consider when studying politically-, ethically-, and/or morally-charged content. For example, Sutherland (2017) discussed the implications of different users posting, viewing, and memorializing Black deaths digitally. Contextualization is key to exploring the dichotomies of memorialization versus commodification and the choice to bear witness versus the choice not to engage. Also, most digital engagement metrics are quantitative (number of users, click-throughs, page views, etc.), which limits the analysis of deeper experiences and interactions better captured by qualitative study [55]. As such, this study uses a mixed-methods approach that collects data from multiple channels.

\section{User-created reviews}

Online user-created reviews provide a unique opportunity for engagement and digital activism. Not surprisingly, however, most research on user-created reviews centers on marketing and product choice decisions. Interestingly, the volume of reviews, not whether reviews are good or bad, is the most important factor for attracting Amazon.com customers [56]. Similarly, how online users rate a movie has no impact on box office revenue, but the number of reviews does, which indicates that reviews can be viewed as a proxy for word-of-mouth spread [57]. These findings could imply that more reviews correlate to more visitors of reviewed physical spaces (such as monuments and statues) and perhaps the number of "negative" protest-related reviews correlates to higher offline engagement as well.

There is also intriguing research on emotional expressions found in online reviews. Non-professional reviewers who actively post on Amazon.com experience a sense of belonging to the "Amazon community" and share high levels of "sensitive information [about] ... family, humans, affect, positive emotions, negative emotions, sadness, cognitive mechanisms, concerns related to work, achievements, leisure and money" [58]. However, consumers consider positive and negative emotional expressions in reviews differently; emotions polarize assessments of the quality and trustworthiness of a reviewer. Reviews expressing negative emotions are viewed as being less informative because users attribute them to reviewers' irrational dispositions, while reviews expressing positive emotions are attributed to positive experiences with the product being reviewed [59]. Emotional content expressed in reviews of contentious physical spaces may reveal similar information.

While scholarly literature has yet to address user-created reviews in terms of activism or political expression, recent news coverage has mentioned the phenomenon in passing. The New York Times reported that Yelp blocked comments for Comet Ping Pong (a pizza restaurant) 
after receiving reports of threatening and abusive comments related to the "Pizzagate" conspiracy [ $\underline{60}$ ]. The Red Hen, a restaurant in northern Virginia, was bombarded with bad reviews after refusing to serve the White House press secretary (Barnes, 2018). Other unaffiliated restaurants with the same name in D.C., New Jersey, and Connecticut experienced collateral damage with hundreds of bad reviews, angry calls, and one instance of a protestor "egging" the wrong restaurant (Siegel, 2018). Clearly, "fake" reviews have real impacts.

Current research related to combating "fake" reviews focuses on detection (Kugler, 2014; Mukherjee, et al., 2013) and policy-making (Malbon, 2013) rather than gauging sentiment or uncovering alternative functions such as activism. Moreover, traditional approaches to the design and evaluation of online review systems enact the capitalist paradigms in which they are often founded (Wilson and De Paoli, 2019). Investigating argumentative reviews may uncover new insights into political expression and engagement - particularly how online behavior influences conceptions of physical spaces and vice versa.

Demographic differences in online reviewers. Currently, there are inconsistent findings on the proportion of men versus women who write online reviews. Mangold and Smith (2012) found men posted more frequently than women based on a survey study of university students [61]. Yet Punj's (2013) analysis of data from the Pew Research Center found that women were more likely to post online reviews [62]. Moreover, these results directly contradict Mangold and Smith's (2012) study, finding "younger male consumers with some college education (possibly because they are still in college) are least likely to post online reviews" [으]. Fogel and Kumar (2017) found no difference in review impact with regards to age or gender, but did find categorical race/ethnicity significance, with "Hispanic American, Asian/Asian American, and Other associated with increased intentions to use an online restaurant review Web site."

\section{Data and methods}

\section{Studying social media data}

The average American now spends almost an hour per day on Facebook-owned applications alone (Stewart, 2016). Dougherty and Meyer (2014) acknowledge that "[a]s more of the daily activities of life are carried out on the Web, the Web pages, sites, and applications that enable those activities and record traces of our communications are increasingly primary media for modern society" [64]. From another perspective, future researchers studying our current time will have to draw heavily from digital content to understand the realities of our lives [65]. Reporting and analyzing Silent Sam's online reviews provides insights into the current sentiments surrounding a contentious physical space.

\section{Analytic strategy}

This study employs qualitative-dominant mixed methods research (MMR). MMR provides "an intellectual and practical synthesis based on qualitative and quantitative research" that often provides "the most informative, complete, balanced, and useful research results" [66]. MMR can be particularly helpful for interpreting quantitative results [67] such as comparing rates of user-engagement (e.g., "likes") and the sentiments expressed in review posts. Additionally, strengths of one method can compensate weaknesses in another [68].

Content analysis. Publicly available review content from the Silent Sam Facebook page was collected and analyzed for this study, including gender expression of unique contributors (via chosen gender pronouns), text from reviews and replies, and reactions ("likes," "loves," etc.). This included 44 original posts and 125 replies created by 67 unique users between October 2015 and February 2019. Facebook posts that "checked in" or "tagged" Silent Sam but did not include a review were not collected. Data was saved on an encrypted platform and pseudonyms were chosen for examples presented in this paper. All users who posted to the page had publicly viewable gendered pronouns selected (i.e., "he" or "her"). None used non-binary gender pronouns. Data was collected on 13 March 2019 and reflects only the publicly visible information available at that time.

Facebook's review system changed from assigning 1-5 stars to asking users to choose "Yes" or "No" to the question, "Would you recommend Silent Sam?" over the period of time in which original posters created their reviews. As such, original posts were coded as "pro-Confederate" if they provided 4-5 stars or expressed that they recommended the statue. Users who gave Silent Sam 1-2 stars or expressed that they did not recommend the monument were coded as "anti-Confederate." The researcher coded replies as pro-Confederate or anti-Confederate depending upon the sentiment expressed inside the posts (e.g., if the replier agreed or disagreed with the original poster).

The researcher then used Herring, et al.'s (2005) CMC Act Taxonomy to code all publicly available original posts. The CMC Act Taxonomy provides a classification scheme for coding online speech acts (Herring, et al., 2005). For example, the post "Put the Statue back up!!!!" was coded as DIRECT, implying an "attempt to cause action" (Herring, et al., 2005). Research that implements these codes includes studies of online chatrooms (Barlow, 2013; Kapidzic and Herring, 2011), contextualizing and framing in forums (Zhang, 2011), and speech patterns of celebrities on Twitter (Nemer, 2016). Next, all SPLC (2019) claims visible in the pro-Confederate recommendation posts were identified and coded; examples are provided in Appendix A, Table A1. To mitigate potential bias and ensure reliable textual content analysis, the researcher enlisted another coder to assign CMC speech acts (Herring, et al. 2005) and SPLC (2019) claims as well. Next, the researcher computed interrated agreement between the two sets of codes and found a Cohen's Kappa coefficient of 0.97, indicating high agreement. The researcher and coder then discussed disputed posts and agreed upon final codes for analysis.

\section{Results}

\section{Reviews and engagement}

In response to $R Q 1$, no statistical significance is found between pro- or anti-Confederate monument recommendations and the number of reactions or comments. Neither is there significance for engagement when gender is added to review sentiment. However, there are demographic patterns that emerge in content creation. 
Demographic patterns. A Fisher exact test shows a statistically significant difference between gender and pro-Confederate versus antiConfederate sentiment expressed on the original review posts $(p=0.009)$. Table 1 displays the frequency counts.

\begin{tabular}{||l|c|c||}
\hline \multicolumn{3}{|c|}{ Table 1: Recommendation sentiment by gender. } \\
\hline \hline & Male & Female \\
\hline \hline Recommends statue & 22 & 7 \\
\hline \hline Does not recommend statue & 5 & 10 \\
\hline
\end{tabular}

Pro-Confederate users made up 65.91 percent of the original reviewers and 68.65 percent of total posters, which, while larger than the 42 percent of Southerners who expressed a desire to leave Confederate monuments standing in a December 2018 Winthrop survey, is not a statistically significant difference in proportion ( $p=0.82$ and $p=0.79$, respectively).

Women made up 38.63 percent of original posters, a statistically significant difference in the gender ratio of reviewers $(z=4.378, p<0.001)$. Additionally, women made up a smaller proportion of pro-Confederate contributors, 24.14 percent original reviewers and 28.26 percent of both reviewers and repliers, which is statistically significant from an equally gendered distribution $(z=5.359$ and $z=6.744, p<0.0001$, respectively). This differs from Strother, et al.'s (2017) finding that women support public displays of Confederate symbolism at a slightly higher rate than men, although these findings do align with Bode's (2017) conclusion that women are less likely to post political information.

While women made up a smaller proportion of unique users, they made more reply posts than men (67 replies written by women compared to 58 replies written by men). However, this finding may be highly skewed due to a "flame war" that occurred between two female posters that garnered 37 reply posts between the two. This will be further discussed in the Flame Wars section below.

\section{Differences in speech acts}

A Fisher's exact test found significant differences between negative and positive reviews ( $p=0.024)$. Of the 44 total original posts, four did not include any text and only nine of the 16 CMC Speech Act categories were coded from the data (see Table 2). The speech acts INFORM and DIRECT were used particularly frequently by users who recommended the monument. Examples of speech acts are available in $\underline{A} p p e n d i x$, Table C1.

\begin{tabular}{|c|c|c|c|c|c|c|c|c|c|c|c|c|}
\hline & & & $\underset{J}{ذ}$ & 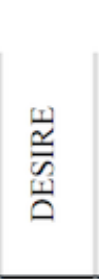 & 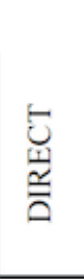 & 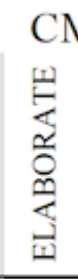 & 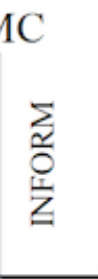 & 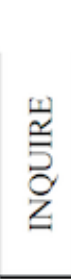 & 式 & 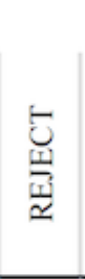 & 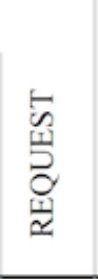 & Total \\
\hline \multirow{3}{*}{$\begin{array}{l}\text { Not } \\
\text { Recommended }\end{array}$} & Count & 2 & 3 & 2 & 1 & 1 & 3 & 0 & 0 & 1 & 2 & 15 \\
\hline & Expected Count & 1.4 & 1.7 & 1.0 & 3.1 & .3 & 5.5 & .3 & .7 & .3 & .7 & 15.0 \\
\hline & Residual & 6 & 1.3 & 1.0 & -2.1 & .7 & -2.5 & -.3 & -.7 & .7 & 1.3 & \\
\hline \multirow[t]{3}{*}{ Recommended } & Count & 2 & 2 & 1 & 8 & 0 & 13 & 1 & 2 & 0 & 0 & 29 \\
\hline & Expected Count & 2.6 & 3.3 & 2.0 & 5.9 & .7 & 10.5 & .7 & 1.3 & .7 & 1.3 & 29.0 \\
\hline & Residual & -.6 & -1.3 & -1.0 & 2.1 & -.7 & 2.5 & .3 & .7 & -.7 & -1.3 & \\
\hline \multirow[t]{2}{*}{ Total } & Count & 4 & 5 & 3 & 9 & 1 & 16 & 1 & 2 & 1 & 2 & 44 \\
\hline & Expected Count & 4.0 & 5.0 & 3.0 & 9.0 & 1.0 & 16.0 & 1.0 & 2.0 & 1.0 & 2.0 & 44.0 \\
\hline
\end{tabular}

Table 2: Recommendation by CMC Speech Act cross-tabulation.

Men created seven of the eight reviews coded as "DIRECT" and 11 of the 13 reviews coded as "INFORM." The high rate of male DIRECT posts aligns with Kapidzic and Herring's (2011) finding of men using more manipulative speech acts [69]. The large proportion of men using INFORM as a speech act can be understood as "mansplaining."

The word mansplain, a portmanteau of man and explain, is used to describe men speaking patronizingly to women as well as a method to critique, evaluate, or comment on the appropriateness of language used on social media (Bridges, 2017). Merriam-Webster (2018; n.d.) added "mansplain" to its online dictionary in 2018 as a verb meaning to "explain something to a woman in a condescending way that assumes she has no knowledge about the topic." Two examples from the Silent Sam review page are excerpted below: 
Mark: Silent Sam represents the heroic and brave soldiers that fought in the War of

Yankee Aggression.

John: In memory of 18, 19 year olds who died ... fight for the confederacy.

Similar "informative" recommendations were written by men throughout the four years of review posts studied. These posts offer little additional information of value beyond what can be read in the page's "About" section, which states that the monument depicts a Confederate soldier (Silent Sam, 2015).

\section{RQ3: Use of coded racism in positive reviews}

Of the 29 original positive reviews of Silent Sam, only 14 aligned with the claims defined by the SPLC (2019). The most popular SPLC claim used was HISTORY. Of the posts that did not include SPLC claims, two new categories emerged: six reviewers simply claimed that the monument must be saved, restored, or respected and two posters directed anyone who felt differently to "leave." Frequency distribution and proportions of claims used are displayed in Table 3; examples are available in Appendix A, Table A1.

\begin{tabular}{||c|c||c||c||c||c|c||c||c||}
\hline \multicolumn{9}{|c|}{ Table 3: Proportion of SPLC claims used by pro-statue reviewers. } \\
\hline \hline & History & $\begin{array}{c}\text { Not } \\
\text { slavery }\end{array}$ & $\begin{array}{c}\text { First } \\
\text { Amendment }\end{array}$ & Heritage & $\begin{array}{c}\text { Slaves } \\
\text { too }\end{array}$ & $\begin{array}{c}\text { Other: } \\
\text { Save/Respect }\end{array}$ & $\begin{array}{c}\text { Other: } \\
\text { Leave }\end{array}$ & $\begin{array}{c}\text { Other: } \\
\text { Misc. }\end{array}$ \\
\hline \hline Cases & 8 & 3 & 1 & 1 & 1 & 6 & 2 & 7 \\
\hline \hline Proportion & 0.28 & 0.10 & 0.03 & 0.03 & 0.03 & 0.21 & 0.07 & 0.24 \\
\hline \hline
\end{tabular}

\section{Other findings}

Flame wars. While analyzing content for instances of flaming was out-of-scope for this study, the Silent Sam review page hosted large amounts of hostile content. Interestingly, gender and whether posts recommended (or did not recommend) the monument did not seem to correspond to either the users who created antagonistic posts or which posts were responded to with flames. Nearly all posts that had comments contained vicious replies. An excerpted portion of the exchange between two women with the highest number of posts on the page is replicated below.

Faith: Dear Lord child. Just shut up. Your digging your hole deeper. Your not the brightest are ya. Bet you make your parents proud. Yuck.

Taryn: yes me respecting freedom of speech does make them proud ...

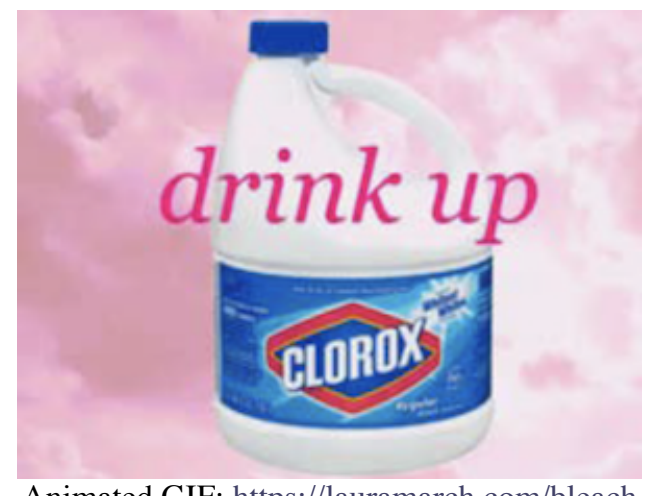

Faith: Derp yep there you go showing it again. Sweetie give you enough rope ... To easy

Taryn: to easy to prove you're dumb ... i agree

Taryn: poor baby ... don't you have a confederate statue to cry over?

Mistaken flames. Users were so willing to flame others that three separate people mistakenly attacked others that shared their own attitude towards the monument. Each of these misguided arguments occurred on an original post that did not recommend Silent Sam, yet took place between repliers expressing pro-Confederate monument sentiments. For example, in response to an original post that critiqued UNC leaders for not "being on the right side of history," a pro-statue user replied, "Like the same folks who committed treason in 1776 ... idiot." This reply was followed up by another user who commented, "Lol sweetie that comment alone. Exactly. 1776 (history). You get it now? You just confirmed love that you're the idiot. Poor thing." Clearly, the last user in this comment chain did not realize the first replier was calling the original poster an "idiot," while also favorably comparing Confederate soldiers to the founding fathers. While O'Sullivan and Flanagin (2003) call for researchers to investigate the function of harsh messages before labeling them as flames, none of the derogatory posts seen on the Silent Sam review page appear to be constructive or appropriate for public discourse.

Zero instances of changed opinions were observed in any reviews or replies. In fact, one user stated, “... your opinion won't change mine" after sparring in yet another flame war. These examples provide additional support for calls to include online self-reflexive listening within contemporary pedagogy (Jones, 2019). 
"Leave" as an implicit slur. Two original posts implore users that do not share their pro-Confederate monument attitudes to "leave" or "go somewhere else."

Dalton: keep him in place, if you don't like him leave.

Kevin: To me this is my state. And all you people comes from other states. If you don't like it go somewhere else. We don't need you here. if not close the college

down for not standing for the history of this state.

This language echoes President Trump's racist tweets and related rhetoric imploring congresswomen of color to "go back" to "the totally broken and crime infested places from which they came" (Trump, 2019). Relatedly, the U.S. Equal Employment Opportunity Commission (2014) cites "go back to where you came from" as an example of language that could violate anti-discrimination employment laws. Moreover, stating that people who do not share the same values should leave is both counterintuitive to social contracts and "not a morally adequate response to the complaints" [뭉.

\section{Discussion and conclusion}

While this study did not find any statistical significance between the sentiment (positive or negative) of a review and the amount of engagement (reactions or comments), there is evidence of sentiment and gender differences between reviewers on the Silent Sam Facebook page. More users wrote pro-Confederate than anti-Confederate reviews. Male reviewers are more likely to recommend the statue than female reviewers. This may seem surprising because women make up the majority of Facebook users (Statistica, n.d.), are slightly more likely to support Confederate monuments in general (Strother, et al., 2017), and produce more online reviews [71]. However, these findings align with previous literature detailing lower levels of active female participation in antagonistic online spaces (Kilgo, et al., 2018; Herring, 1993; 1992).

Rather than offering space for civil discussion, the review function on Silent Sams Facebook page seems to provide a forum for men to "mansplain" the purpose of Confederate memorials. The overwhelming presence of vitriolic messages and lack of civil discourse is also noted.

New themes arose from pro-Confederate reviewers that were not identified by the SPLC (2019). The most frequent claim used by pro-statue reviewers referred to its historical significance. As Strother, et al. (2017) found, knowledge of Southern history negatively correlates with support for Confederate symbolism. Moreover, two users specifically called for people who did not support the public display of Confederate memorialization to "leave." Integrating these findings into the SPLC (2019) claims and rebuttals can guide activists, educators, and social media designers to better address coded racism and democratic values.

Future research and limitations. The deaths of George Floyd, Breonna Taylor, and other Black Americans at the hands of law enforcement in 2020 led to renewed national attention to symbols of the Confederacy and further interest in anti-racist practices. On the Silent Sam Facebook review page, two additional "check in" posts with seven corresponding reply comments were created specifically in response Black Lives Matter protests and counter-protests on 3 June 2020 and 5 August 2020. Future research is needed to examine links between Confederate monuments, pro-police demonstrations, anti-racist work and how related debates play out in unexpected digital spaces including online reviews.

Moreover, whereas the Silent Sam statue has many reviews and "check in" posts on Facebook, there are none visible on Google Reviews or Yelp as of 6 September 2020. However, the Robert E. Lee statue in Richmond, Va. has over 280 posts on Google Reviews but only six Yelp reviews and one Facebook review. The Nathan Bedford Forrest equestrian statue in Nashville, Tenn. has 19 Google reviews, six Yelp reviews, and none on Facebook. Future research is needed to identify potential explanations for these differences.

It is also important to recognize that this study only analyzes content available on one Confederate monument's review page and may not be generalizable to other sites. Furthermore, the lack of significant findings may likely be a result of small sample sizes. The data used in this study was collected in spring 2019 and reflects only the publicly visible information available at that time. Additional posts and replies may have been added after this date and it is possible that users have changed their opinions of the statue, public display preferences, or public gender expressions. Nevertheless, this study provides a starting point for a number of areas for future research on user-generated reviews, online political discussions, and the effects of gender on social media. Fm

\section{About the author}

Laura March is an instructional designer and Web developer. She holds a M.Ed. in learning, design, and technology and a M.S. in art education from the Pennsylvania State University and is currently pursuing a Ph.D. at the School of Information and Library Science at the University of North Carolina at Chapel Hill.

E-mail: laura [dot] march [at] unc [dot] edu

\section{Acknowledgements}

The author would like to thank Eliscia Kinder for her assistance with coding data, Dr. Cal Lee for his guidance and insight, and First Monday's anonymous reviewers for their helpful comments.

\section{Notes}


2. Hahn, 2018, pp. 398-399; SPLC, 2019; Hughey and Daniels, 2013.

3. SPLC, 2019, p. 3.

4. Eddington, 2018, p. 10.

5. Correa, et al., 2010, p. 252.

6. Sinclair-Chapman, 2018, p. 319.

7. Sinclair-Chapman, 2018, p. 319; Fortin, 2017.

8. SPLC, 2019; Hahn, 2018, p. 400.

9. Morgan, 2018, p. 157.

10. Hahn, 2018, p. 402.

11. Carr, 1913; Brundage, 2018, p. 326.

12. Yaros, 2012, p. 60.

13. Montalvo, 2011, p. 91.

14. Lehmann, et al., 2012, p. 164.

15. Organisation for Economic Co-operation and Development (OECD), 2007, p. 18.

16. Östman, 2012, p. 1,006.

17. Organisation for Economic Co-operation and Development (OECD), 2007, p. 18.

18. Ellison and boyd, 2013, p. 5.

19. Tufekci, 2017, p. 151.

20. Tufekci, 2017, p. 38.

21. Earl and Kimport, 2011, p. 25.

22. Tran, et al., 2011, p. 57.

23. Earl and Kimport, 2011, p. 205.

24. Gil de Zúñiga, et al., 2012, p. 331.

25. Barnidge, 2017, p. 316.

26. Lane, et al., 2017, p. 10.

27. Barberá, et al., 2015, p. 1,531.

28. Guerrero-Solé, 2018, p. 10.

29. Agur and Frisch, 2019, p. 9.

30. Wollebæk, et al., 2019, p. 1.

31. Müller and Schwarz, 2017, p. 1.

32. Eddington, 2018, p. 9.

33. Gantt Shafer, 2017, p. 8.

34. Hutchens, et al., 2015, p. 1,204.

35. Herring, 1993, p. 10.

36. Hutchens, et al., 2015, p. 1,210.

37. Cirucci, 2017, p. 4.

38. Bivens and Haimson, 2016, p. 3.

39. Cirucci, 2017, p. 5.

40. Kimbrough, et al., 2013, p. 898. 
41. Kapidzic and Herring, 2011, p. 47.

42. Correa, et al., 2010, p. 252.

43. Ibid.

44. Kilgo, et al., 2018, p. 6.

45. Kilgo, et al., 2018, p. 7.

46. Herring, 1993, p. 1.

47. Bode, 2017, p. 598.

48. Bivens and Haimson, 2016, p. 1.

49. Tatarchevskiy, 2011, p. 298.

50. Earl and Kimport, 2011, p. 179.

51. Amin, 2010, p. 66.

52. Neumayer and Raffl, 2008; Earl and Kimport, 2011, p. 69; Harlow, 2012.

53. boyd, 2007, p. 12 .

54. Bowen and Nemanic, 2010, p. 49.

55. Lehmann, et al., 2012, pp. 164-165; Hale, et al., 2017.

56. Ren, et al., 2018, p. 449.

57. Duan, et al., 2008, p. 1,007.

58. Fornaciari, 2013, p. 1.

59. Kim and Gupta, 2012, p. 985.

60. Kang, 2016, p. 5.

61. Mangold and Smith, 2012,p. 146.

62. Punj, 2013, p. 104.

63. Punj, 2013, p. 106.

64. Dougherty and Meyer, 2014, p. 2,195.

65. Brügger and Schroeder, 2017, p. 1.

66. Johnson, et al., 2007, p. 129.

67. Fidel, 2008, p. 271.

68. Creswell and Plano Clark, 2011, p. 17.

69. Kapidzic and Herring, 2011, p. 47.

70. Fried, 2003, p. 70.

71. Punj, 2013, p. 104.

\section{References}

Colin Agur and Nicholas Frisch, 2019. "Digital disobedience and the limits of persuasion: Social media activism in Hong Kong's 2014 Umbrella Movement," Social Media + Society (January). doi: https://doi.org/10.1177/2056305119827002, accessed 15 April 2019.

Ramtin Amin, 2010. "The empire strikes back: Social media uprisings and the future of cyberactivism," Kennedy School Review, volume 10, pp. 64-67.

AP News, 2019. "Confederate statue supporters to rally at former 'Silent Sam' location over removal request" (4 January), at https://apnews.com/00f5ab6c489d81a3b5ee01d2c77abdb4, accessed 18 April 2019. 
Eytan Bakshy, 2012. "Rethinking information diversity in networks," Notes of the Facebook data team, at

https://www.facebook.com/notes/facebook-data-science/rethinkinginformation-diversity-in-networks/10150503499618859, accessed 12 November 2020.

Pablo Barberá, John T. Jost, Jonathan Nagler, Joshua A. Tucker, and Richard Bonneau, 2015. “Tweeting from left to right: Is online political communication more than an echo chamber?” Psychological Science, volume 26, number 10, pp. 1,531-1,542.

doi: https://doi.org/10.1177/0956797615594620, accessed 12 November 2020.

Jordan B. Barlow, 2013. "Emergent roles in decision-making tasks using group chat," CSCW '13: Proceedings of the 2013 Conference on Computer Supported Cooperative Work, pp. 1,505-1,514.

doi: https://doi.org/10.1145/2441776.2441948, accessed 7 February 2019.

Tom Barnes, 2018. "Restaurant that turned away Sarah Huckabee Sanders bombarded with bad reviews," Independent (25 June), at https://www.independent.co.uk/news/world/americas/red-hen-restaurant-sarah-huckabee-sanders-bad-reviews-yelp-virginia-trump-twittera8416231.html, accessed 10 November 2018.

Matthew Barnidge, 2017. "Exposure to political disagreement in social media versus face-to-face and anonymous online settings," Political Communication, volume 34, number 2, pp. 302-321.

doi: https://doi.org/10.1080/10584609.2016.1235639, accessed 12 November 2020.

Rena Bivens and Oliver L. Haimson, 2016. "Baking gender into social media design: How platforms shape categories for users and advertisers," Social Media + Society (12 October).

doi: https://doi.org/10.1177/2056305116672486, accessed 25 April 2019.

Leticia Bode, 2017. "Closing the gap: Gender parity in political engagement on social media," Information, Communication \& Society, volume 20, number 4, pp. 587-603.

doi: https://doi.org/10.1080/1369118X.2016.1202302, accessed 12 November 2020.

Lynn Bonner, 2015. "Controversy over Confederate memorial 'Silent Sam' reigns at UNC-CH as supporters rally,” News \& Observer (25 October), at https://www.newsobserver.com/news/local/counties/orange-county/article41408412.html, accessed 4 February 2019.

Andrei Boutyline and Robb Willer, 2016. "The social structure of political echo chambers: Variation in ideological homophily in online networks," Political Psychology, volume 38, number 3, pp. 551-569.

doi: https://doi.org/10.1111/pops.12337, accessed 12 November 2020.

Tracey Bowen and Mary-Lou Nemanic (editors), 2010. Cultural production in virtual and imagined worlds. Newcastle upon Tyne: Cambridge Scholars Publishing.

danah boyd, 2007. "Why youth (heart) social network sites: The role of networked publics in teenage social life," In: David Buckingham (editor). Youth, identity, and media. Cambridge, Mass.: MIT Press, pp. 119-142.

danah m. boyd and Nicole B. Ellison, 2007. "Social network sites: Definition, history, and scholarship," Journal of Computer-Mediated Communication, volume 13, number 1, pp. 210-230.

doi: https://doi.org/10.1111/j.1083-6101.2007.00393.x, accessed 12 November 2020.

Judith Bridges, 2017. “Gendering metapragmatics in online discourse: 'Mansplaining man gonna mansplain ...', Discourse, Context \& Media, volume 20, pp. 94-102.

doi: https://doi.org/10.1016/j.dcm.2017.09.010, accessed 5 May 2019.

Niels Brügger and Ralph Schroeder (editors), 2017. The Web as history. London: UCL Press, at http://discovery.ucl.ac.uk/1542998/, accessed 1 November 2018.

W. Fitzhugh Brundage, 2018. "Exclusion, inclusion, and the politics of Confederate commemoration in the American South," Politics, Groups, and Identities, volume 6, number 2, pp. 324-330.

doi: https://doi.org/10.1080/21565503.2018.1454332, accessed 12 November 2020.

Julian Carr, 1913. "Unveiling of Confederate monument at University" (2 June), at https://exhibits.lib.unc.edu/items/show/5519, accessed 3 February 2019.

Angela M. Cirucci, 2017. "Normative interfaces: Affordances, gender, and race in Facebook," Social Media + Society (28 June).

doi: https://doi.org/10.1177/2056305117717905, accessed 15 April 2019.

Teresa Correa, Amber Willard Hinsley, and Homero Gil de Zúñiga, 2010. "Who interacts on the Web? The intersection of users' personality and social media use," Computers in Human Behavior, volume 26, number 2, pp. 247-253.

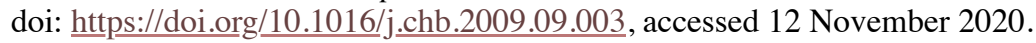

Holland Cotter, 2017. "We need to move, not destroy, Confederate monuments," New York Times (20 August), at https://www.nytimes.com/2017/08/20/arts/design/we-need-to-move-not-destroy-confederate-monuments.html, accessed 12 November 2020.

John W. Creswell and Vicki L. Plano Clark, 2011. Designing and conducting mixed methods research. Second edition. Los Angeles: Sage.

Meghan Dougherty and Eric T. Meyer, 2014. "Community, tools, and practices in Web archiving: The state-of-the-art in relation to social science and humanities research needs," Journal of the Association for Information Science and Technology, volume 65, number 11, pp. 2,1952,209 .

doi: https://doi.org/10.1002/asi.23099, accessed 12 November 2020. 
Wenjing Duan, Bin Gu, and Andrew B. Whinston, 2008. "Do online reviews matter? - An empirical investigation of panel data," Decision Support Systems, volume 45, number 4, pp. 1,007-1,016.

doi: https://doi.org/10.1016/j.dss.2008.04.001, accessed 12 November 2020.

Jennifer Earl and Katrina Kimport, 2011. Digitally enabled social change: Activism in the Internet age. Cambridge, Mass.: MIT Press.

Sean M. Eddington, 2018. "The communicative constitution of hate organizations online: A semantic network analysis of 'Make America Great Again,,"Social Media + Society (7 August).

doi: https://doi.org/10.1177/2056305118790763, accessed 15 April 2019.

Nicole B. Ellison and danah m. boyd, 2013. "Sociality through social network sites," In: W.H. Dutton (editor). Oxford handbook of Internet studies. New York: Oxford University Press, pp. 151-172.

doi: https://doi.org/10.1093/oxfordhb/9780199589074.013.0008, accessed 1 November 2018.

Facebook, n.d.-a. “Log in or sign up,” at https://www.facebook.com, accessed 20 June 2019.

Facebook, n.d.-b. "Discriminatory practices," at https://www.facebook.com/policies/ads/prohibited content/discriminatory_practices, accessed 2 May 2019.

Facebook, n.d.-c. "Automated ads [Latino]," at https://www.facebook.com/PSUCrisis/promotions/?refSource=pages_manager_bar, accessed 20 June 2019.

Facebook, n.d.-d. "Automated ads [Asian]," at https://www.facebook.com/PSUCrisis/promotions/?refSource=pages manager bar, accessed 20 June 2019 .

Facebook, n.d.-e. "Automated ads [African]," at https://www.facebook.com/PSUCrisis/promotions/?refSource=pages manager bar, accessed 20 June 2019.

Dana R. Fisher, Dawn M. Dow, and Rashawn Ray, 2017. "Intersectionality takes it to the streets: Mobilizing across diverse interests for the Women's March," Science Advances, volume 3, number 9, peaao1390.

doi: https://doi.org/10.1126/sciadv.aao1390, accessed 12 November 2020.

Joshua Fogel and Mohit Kumar, 2017. "Intentions to use an online restaurant review Web site and purchase behavior after reading reviews," First Monday, volume 22, number 5, at https://firstmonday.org/article/view/7250/6174, accessed 16 July 2019.

doi: https://doi.org/10.5210/fm.v22i5.7250, accessed 12 November 2020.

Federica Fornaciari, 2013. “Amazon is my hangout! Self-disclosure and community building in Amazon's reviews,” AoIR Selected Papers of Internet Research, volume 3, at https://journals.uic.edu/ojs/index.php/spir/article/view/8410/0, accessed 2 November 2018.

Jacey Fortin, 2017. “The statue at the center of Charlottesville's storm," New York Times (13 August), at

https://www.nytimes.com/2017/08/13/us/charlottesville-rally-protest-statue.html, accessed 4 February 2019.

Barbara H. Fried, 2003. "'If you don't like it, leave it': The problem of exit in social contractarian arguments,” Philosophy \& Public Affairs, volume 31, number 1, pp. 40-70.

doi: https://doi.org/10.1111/j.1088-4963.2003.00040.x, accessed 12 November 2020.

Peter Galuszka, 2017. "The women who erected Confederate statues are stunningly silent," Washington Post (13 October), at https://www.washingtonpost.com, accessed 4 February 2019.

Homero Gil de Zúñiga, Logan Molyneux, and Pei Zheng, 2014. "Social media, political expression, and political participation: Panel analysis of lagged and concurrent relationships," Journal of Communication, volume 64, number 4, pp. 612-634.

doi: https://doi.org/10.1111/jcom.12103, accessed 12 November 2020.

Homero Gil de Zúñiga, Nakwon Jung, and Sebastián Valenzuela, 2012. "Social media use for news and individuals' social capital, civic engagement and political participation," Journal of Computer-Mediated Communication, volume 17, number 3, pp. 319-336.

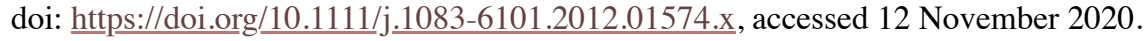

Katie Day Good, 2012. "From scrapbook to Facebook: A history of personal media assemblage and archives," New Media \& Society, volume 15 , number 4, pp. 557-573.

doi: https://doi.org/10.1177/1461444812458432, accessed 12 November 2020

Frederic Guerrero-Solé, 2018. “Interactive behavior in political discussions on Twitter: Politicians, media, and citizens' patterns of interaction in the 2015 and 2016 electoral campaigns in Spain," Social Media + Society (11 November).

doi: https://doi.org/10.1177/2056305118808776, accessed 15 April 2019.

Barbara Hahn, 2018. "Conflicting commemorations: Past and present in Confederate memorialization," Management \& Organizational History, volume 13, number 4, pp. 397-403.

doi: https://doi.org/10.1080/17449359.2018.1525406, accessed 12 November 2020.

Scott A. Hale, Grant Blank, and Victoria D. Alexander, 2017. "Live versus archive: Comparing a Web archive to a population of Web pages," In: Niels Brügger and Ralph Schroeder (editors). The Web as history. London: UCL Press, pp. 45-61, and at

http://discovery.ucl.ac.uk/1542998/, accessed 1 November 2018.

Summer Harlow, 2012. "Social media and social movements: Facebook and an online Guatemalan justice movement that moved offline," New Media \& Society, volume 14, number 2, pp. 225-243. 
doi: https://doi.org/10.1177/1461444811410408, accessed 12 November 2020.

Susan C. Herring, 1993. "Gender and democracy in computer-mediated communication," Electronic Journal of Communication, volume 3, number 2, at http://www.cios.org/EJCPUBLIC/003/2/00328.HTML, accessed 28 April 2019.

Susan C. Herring, 1992. "Gender and participation in computer-mediated linguistic discourse," paper presented at the annual meeting of the Linguistic Society of America, at https://eric.ed.gov/?id=ED345552, accessed 28 April 2019.

Susan C. Herring, Anupam Das, and Shashikant Penumarthy, 2005. “CMC act taxonomy,” at http://ella.slis.indiana.edu/ herring/cmc.acts.html, accessed 29 January 2019.

Steve Hinkle, Lee Fox-Cardamone, Julia A. Haseleu, Rupert Brown, and Lois M. Irwin, 1996. "Grassroots political action as an intergroup phenomenon," Journal of Social Issues, volume 52, number 1, pp. 39-51.

doi: https://doi.org/10.1111/j.1540-4560.1996.tb01360.x , accessed 12 November 2020.

David James Hudson, 2017. “On 'diversity' as anti-racism in library and information studies: A critique,” Journal of Critical Library and Information Studies, volume 1, number 1, at https://journals.litwinbooks.com/index.php/jolis/article/view/6, accessed 13 September 2018. doi: https://doi.org/10.24242/jclis.v1i1.6, accessed 12 November 2020.

Matthew W. Hughey and Jessie Daniels, 2013. "Racist comments at online news sites: A methodological dilemma for discourse analysis," Media, Culture \& Society, volume 35, number 3, pp. 332-347.

doi: https://doi.org/10.1177/0163443712472089, accessed 12 November 2020.

Myiah J. Hutchens, Vincent J. Cicchirillo, and Jay D. Hmielowski, 2015. "How could you think that?!?!: Understanding intentions to engage in political flaming," New Media \& Society, volume 17, number 8, pp. 1,201-1,219.

doi: https://doi.org/10.1177/1461444814522947, accessed 12 November 2020.

R. Burke Johnson, Anthony J. Onwuegbuzie, and Lisa A. Turner, 2007. “Toward a definition of mixed methods research,” Journal of Mixed Methods Research, volume 1, number 2, pp. 112-133.

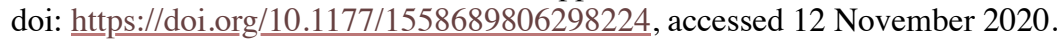

L. Corinne Jones, 2019. "Listening to lies and legitimacy online: A proposal for digital rhetorical listening," First Monday, volume 24, number 3, at https://firstmonday.org/article/view/9170/7723, accessed 16 July 2019.

doi: https://doi.org/10.5210/fm.v24i3.9170, accessed 12 November 2020.

Peter Jones, 2012. "The Arab Spring: Opportunities and implications," International Journal: Canada's Journal of Global Policy Analysis, volume 67, number 2, pp. 447-463.

doi: https://doi.org/10.1177/002070201206700214, accessed 12 November 2020.

Cecilia Kang, 2016. "Fake news onslaught targets pizzeria as nest of child-trafficking," New York Times (21 November), at https://www.nytimes.com/2016/11/21/technology/fact-check-this-pizzeria-is-not-a-child-trafficking-site.html, accessed 9 November 2018.

Sanja Kapidzic and Susan C. Herring, 2011. "Gender, communication, and self-presentation in teen chatrooms revisited: Have patterns changed?" Journal of Computer-Mediated Communication, volume 17, number 1, pp. 39-59.

doi: https://doi.org/10.1111/j.1083-6101.2011.01561.x, accessed 12 November 2020.

Danielle K. Kilgo, Yee Man Margaret Ng, Martin J. Riedl, and Ivan Lacasa-Mas, 2018. "Reddit's veil of anonymity: Predictors of engagement and participation in media environments with hostile reputations," Social Media + Society (11 November).

doi: https://doi.org/10.1177/2056305118810216, accessed 15 April 2019.

Junyong Kim and Pranjal Gupta, 2012. "Emotional expressions in online user reviews: How they influence consumers' product evaluations," Journal of Business Research, volume 65, number 7, pp. 985-992.

doi: https://doi.org/10.1016/j.jbusres.2011.04.013, accessed 12 November 2020.

Amanda M. Kimbrough, Rosanna E. Guadagno, Nicole L. Muscanell, and Janeann Dill, 2013. "Gender differences in mediated communication: Women connect more than do men," Computers in Human Behavior, volume 29, number 3, pp. 896-900.

doi: https://doi.org/10.1016/j.chb.2012.12.005, accessed 12 November 2020.

Hanna Krasnova, Natasha F. Veltri, Nicole Eling, and Peter Buxmann, 2017. "Why men and women continue to use social networking sites: The role of gender differences," Journal of Strategic Information Systems, volume 26, number 4, pp. $261-284$.

doi: https://doi.org/10.1016/j.jsis.2017.01.004, accessed 12 November 2020.

Logan Kugler, 2014. "Keeping online reviews honest," Communications of the ACM, volume 57, number 11, pp. 20-23.

doi: https://doi.org/10.1145/2667111, accessed 12 November 2020.

Daniel S. Lane, Dam Hee Kim, Slgi S. Lee, Brian E. Weeks, and Nojin Kwak, 2017. "From online disagreement to offline action: How diverse motivations for using social media can increase political information sharing and catalyze offline political participation," Social Media + Society (17 July).

doi: https://doi.org/10.1177/2056305117716274, accessed 15 April 2019.

Janette Lehmann, Mounia Lalmas, Elad Yom-Tov, and Georges Dupret, 2012. "Models of user engagement,” In: Judith Masthoff, Bamshad Mobasher, Michel C. Desmarais, and Roger Nkambou (editors). User modeling, adaptation, and personalization. Lecture Notes in Computer Science, volume 7379. Berlin: Springer, pp. 164-175.

doi: https://doi.org/10.1007/978-3-642-31454-4_14, accessed 10 November 2018. 
Barbara L. Ley and Paul R. Brewer, 2018. "Social media, networked protest, and the march for science," Social Media + Society (13 August). doi: http://journals.sagepub.com/doi/10.1177/2056305118793407, accessed 15 April 2019.

Travis Long, 2018. "Silent Sam statue comes down as protesters and police clash at rally at UNC," News \& Observer (20 August), at https://www.newsobserver.com/news/local/article217056770.html, accessed 18 April 2019.

Justin Malbon, 2013. “Taking fake online consumer reviews seriously,” Journal of Consumer Policy, volume 36, pp. 139-157. doi: https://doi.org/10.1007/s10603-012-9216-7, accessed 12 November 2020.

W. Glynn Mangold and Katherine Taken Smith, 2012. "Selling to millennials with online reviews," Business Horizons, volume 55, number 2, pp. 141-153.

doi: https://doi.org/10.1016/j.bushor.2011.11.001, accessed 12 November 2020.

Merriam-Webster, 2018. "Mansplaining: Words we're watching," at https://www.merriamwebster.com/words-at-play/mansplaining-definitionhistory, accessed 23 July 2019.

Merriam-Webster, n.d. "Definition of mansplain," at https://www.merriamwebster.com/dictionary/mansplaining, accessed 2 May 2019.

Roberto E. Montalvo, 2011. “Social media management," International Journal of Management \& Information Systems, volume 15, number 3, pp. 91-96.

doi: https://doi.org/10.19030/ijmis.v15i3.4645, accessed 12 November 2020.

David Morgan, 2018. "Soldier statues and empty pedestals: Public memory in the wake of the Confederacy," Material Religion, volume 14, number 1, pp. 153-157.

doi: https://doi.org/10.1080/17432200.2017.1418231, accessed 12 November 2020.

Arjun Mukherjee, Vivek Venkataraman, Bing Liu, and Natalie Glance, 2013. "Fake review detection: Classification and analysis of real and pseudo reviews," Technical report, Department of Computer Science, University of Illinois at Chicago, UIC-CS-201303, and at https://pdfs.semanticscholar.org/4c52/1025566e6afceb9adcf27105cd33e4022fb6.pdf, accessed 10 November 2018.

Karsten Müller and Carlo Schwarz, 2018. "From hashtag to hate crime: Twitter and anti-minority sentiment," SSRN Electronic Journal (28 March), at https://www.ssrn.com/abstract=3149103, accessed 31 January 2019.

Karsten Müller and Carlo Schwarz, 2017. "Fanning the flames of hate: Social media and hate crime," SSRN Electronic Journal (7 December), at https://www.ssrn.com/abstract=3082972, accessed 31 January 2019.

Nicole L. Muscanell and Rosanna E. Guadagno, 2012. "Make new friends or keep the old: Gender and personality differences in social networking use," Computers in Human Behavior, volume 28, number 1, pp. 107-112.

doi: https://doi.org/10.1016/j.chb.2011.08.016, accessed 12 November 2020.

David Nemer, 2016. "Celebrities acting up: A speech act analysis in tweets of famous people," Social Networking, volume 05, number 1, pp. 110, and at http://www.i-scholar.in/index.php/SN/article/view/95633, accessed 12 November 2020.

Christina Neumayer and Raffl Celina, 2009. "Facebook for global protest: The potential and limits of social software for grassroots activism," at http://cirn.infotech.monash.edu.au/assets/docs/prato2008papers/raffl.pdf, accessed 10 November 2018.

An Nguyen and Hong Tien Vu, 2019. "Testing popular news discourse on the 'echo chamber' effect: Does political polarisation occur among those relying on social media as their primary politics news source?" First Monday, volume 24, number 6, at

https://firstmonday.org/article/view/9632/7807, accessed 16 July 2019.

doi: https://doi.org/10.5210/fm.v24i6.9632, accessed 12 November 2020.

Organisation for Economic Co-operation and Development (OECD), 2007. "Participative Web and user-created content: Web 2.0, wikis and social networking," at https://www.oecd.org/sti/ieconomy/participativewebanduser-createdcontentweb20wikisandsocialnetworking.htm, accessed 10 November 2018.

Patrick B. O’Sullivan and Andrew J. Flanagin, 2003. "Reconceptualizing 'flaming' and other problematic messages," New Media \& Society, volume 5, number 1, pp. 69-94.

doi: https://doi.org/10.1177/1461444803005001908, accessed 12 November 2020.

Pew Research Center, 2019. "Social media fact sheet" (12 June), at https://www.pewinternet.org/fact-sheet/social-media/, accessed 25 April 2019.

Girish N. Punj, 2013. "Do consumers who conduct online research also post online reviews? A model of the relationship between online research and review posting behavior," Marketing Letters, volume 24, pp. 97-108.

doi: https://doi.org/10.1007/s11002-012-9205-2, accessed 12 November 2020.

Jie Ren, William Yeoh, Mong Shan Ee, and Aleš Popovič, 2018. "Online consumer reviews and sales: Examining the chicken-egg relationships," Journal of the Association for Information Science and Technology, volume 69, number 3, pp. 449-460.

doi: https://doi.org/10.1002/asi.23967, accessed 12 November 2020.

James Chase Sanchez and Kristen R Moore, 2015. "Reappropriating public memory: Racism, resistance and erasure of the Confederate defenders of Charleston monument," Present Tense: A Journal of Rhetoric in Society, volume 5, number 2, at

http://www.presenttensejournal.org/wp-content/uploads/2015/12/SanchezMoore.pdf, accessed 29 January 2019. 
Cynthia L. Selfe and Paul R. Meyer, 1991. “Testing claims for on-line conferences,” Written Communication, volume 8, number 2, pp. 163192.

doi: https://doi.org/10.1177/0741088391008002002, accessed 12 November 2020.

Rachel Siegel, 2018. "This is what happens when your restaurant is also called Red Hen," Washington Post (25 June), at https://www.washingtonpost.com/, accessed 10 November 2018.

Silent Sam, 2015. "Silent Sam monument," at https://www.facebook.com/pages/Silent- Sam/112304058786774, accessed 2 May 2019.

Valeria Sinclair-Chapman, 2018. "(De)constructing symbols: Charlottesville, the confederate flag, and a case for disrupting symbolic meaning," Politics, Groups, and Identities, volume 6, number 2, pp. 316-323.

doi: https://doi.org/10.1080/21565503.2018.1455597, accessed 12 November 2020.

Southern Poverty Law Center (SPLC), 2019. "Whose heritage? Public symbols of the Confederacy" (1 February), at https://www.splcenter.org/20190201/whose-heritage-public-symbols-confederacy, accessed 29 January 2019.

Southern Poverty Law Center (SPLC), 2016. "Whose heritage? Community action guide" (21 April), at https://www.splcenter.org/20160421/whose-heritage-community-action-guide, accessed 29 January 2019.

Jane Stancill, 2019. “After a whirlwind week in Chapel Hill, Silent Sams future is far from settled,” News \& Observer, at https://www.newsobserver.com/, accessed 4 February 2019.

Statista, n.d. "Facebook U.S. user gender share 2018," at https://www.statista.com/statistics/266879/facebook-users-in-the-us-by=gender/, accessed 29 April 2019.

Alexander H. Stephens, 1861. "Cornerstone speech" (21 March), at

https://www.encyclopediavirginia.org/Cornerstone_Speech_by_Alexander_H_Stephens_March_21_1861, accessed 7 February 2019.

James B. Stewart, 2016. "Facebook has 50 minutes of your time each day. It wants more," New York Times (5 May), at https://www.nytimes.com/2016/05/06/business/facebook-bends-the-rules-of-audience-engagement-to-its-advantage.html, accessed 10 November 2018.

Logan Strother, Spencer Piston, and Thomas Ogorzalek, 2017. "Pride or prejudice? Racial prejudice, Southern heritage, and White support for the confederate battle flag," Du Bois Review: Social Science Research on Race, volume 14, number 1, pp. $295-323$.

doi: https://doi.org/10.1017/S1742058X17000017, accessed 12 November 2020.

Cass R. Sunstein, 2017. \#Republic: Divided democracy in the age of social media. Princeton, N.J.: Princeton University Press.

Tonia Sutherland, 2017. "Making a killing: On race, ritual, and (re)membering in digital culture," Preservation, Digital Technology \& Culture, volume 46 , number 1 , pp. 32-40.

doi: https://doi.org/10.1515/pdtc-2017-0025, accessed 13 September 2018.

Tatiana Tatarchevskiy, 2011. “The 'popular' culture of Internet activism,” New Media \& Society, volume 13, number 2, pp. $297-313$. doi: https://doi.org/10.1515/pdtc-2017-0025, accessed 13 September 2018.

Janet Tran, Anthony Pennay, and Krista Kohlhausen, 2011. "Civic dialogue courtesy of social media," Social Studies Review, volume 50, number 1, pp. 56-59.

Donald J. Trump, 2019. “... and viciously telling the people of the United States, the greatest and most powerful Nation on earth, how our government is to be run. Why don't they go back and help fix the totally broken and crime infested places from which they came. Then come back and show us how ..." (14 July), at https://twitter.com/realDonaldTrump/status/1150381395078000643, accessed 25 July 2019.

Zeynep Tufekci, 2017. Twitter and tear gas: The power and fragility of networked protest. New Haven, Conn.: Yale University Press.

Zeynep Tufekci and Christopher Wilson, 2012. "Social media and the decision to participate in political protest: Observations From Tahrir Square," Journal of Communication, volume 62, number 2, pp. 363-379.

doi: https://doi.org/10.1111/j.1460-2466.2012.01629.x, accessed 12 November 2020.

U.S. Equal Employment Opportunity Commission (EEOC), 2014. "Employment rights of immigrants under federal anti-discrimination laws" (29 April), at https://www.eeoc.gov/laws/guidance/employment-rights-immigrants-under-federal-anti-discrimination-laws-brochure, accessed 25 July 2019.

UNC Archives, 2018. "A guide to resources about UNC's Confederate monument: Timeline," at https://exhibits.lib.unc.edu/exhibits/show/silent-sam/timeline, accessed 3 February 2019.

Anna Wilson and Stefano De Paoli, 2019. "On the ethical and political agency of online reputation systems," First Monday, volume 24, number 2, at https://firstmonday.org/article/view/9393/7730, accessed 16 July 2019.

doi: https://doi.org/10.5210/fm.v24i2.9393, accessed 12 November 2020.

Winthrop University, 2018. “Winthrop Poll: Southern Focus Survey,” at https://www.winthrop.edu/winthroppoll/wupoll-2018-results.aspx, accessed 2 May 2019.

Dag Wollebæk, Rune Karlsen, Kari Steen-Johnsen and Bernard Enjolras, 2019. “Anger, fear, and echo chambers: The emotional basis for online behavior," Social Media + Society (9 April).

doi: https://doi.org/10.1177/2056305119829859, accessed 15 April 2019. 
Samantha Z. Yammine, Christine Liu, Paige B. Jarreau, and Imogen R. Coe, 2018. "Social media for social change in science," Science, volume 360, number 6385 (13 April), pp. 162-163.

doi: https://doi.org/10.1126/science.aat7303, accessed 12 November 2020.

Ronald A. Yaros, 2012. "Social media in education: Effects of personalization and interactivity on engagement and collaboration," In: Hana S. Noor Al-Deen and John A. Hendricks (editors). Social media: Usage and impact. Lanham, Md.: Lexington Books, pp. 57-74.

Guo Zhang, 2011. "Age, culture, and communication: Contextualization and framing in a playful online forum," Proceedings of the American Society for Information Science and Technology, volume 48, number 1, pp. 1-9.

doi: https://doi.org/10.1002/meet.2011.14504801029, accessed 12 November 2020.

\section{Appendix A}

Table A1: Claims and responses to Confederate memorials, adapted from SPLC (2018).

\begin{tabular}{|c|c|c|c|}
\hline Claim & $\begin{array}{l}\text { SPLC (2018) } \\
\text { response }\end{array}$ & $\begin{array}{c}\text { Example from } \\
\text { data }\end{array}$ & $\begin{array}{c}\text { Frequency } \\
\text { in data }\end{array}$ \\
\hline $\begin{array}{l}\text { Removing } \\
\text { this } \\
\text { Confederate } \\
\text { symbol is } \\
\text { erasing } \\
\text { history in the } \\
\text { name of } \\
\text { political } \\
\text { correctness. }\end{array}$ & $\begin{array}{l}\text { This is not an } \\
\text { attempt to erase } \\
\text { history. It is an effort } \\
\text { to end the } \\
\text { government's } \\
\text { endorsement of a } \\
\text { symbol that has } \\
\text { always represented } \\
\text { the oppression of an } \\
\text { entire race. These } \\
\text { historical symbols } \\
\text { belong in museums } \\
\text { and other } \\
\text { educational settings } \\
\text { where people can } \\
\text { see them and learn } \\
\text { the full history of } \\
\text { slavery, the } \\
\text { Confederacy, the } \\
\text { Civil War and Jim } \\
\text { Crow. }\end{array}$ & $\begin{array}{l}\text { "it's ridiculous that } \\
\text { these little } \\
\text { snowflakes are } \\
\text { trying to erase } \\
\text { history!! good or } \\
\text { bad!!!"” }\end{array}$ & 8 \\
\hline $\begin{array}{l}\text { The Civil } \\
\text { War wasn't } \\
\text { about slavery. } \\
\text { It was about } \\
\text { states' rights. }\end{array}$ & $\begin{array}{l}\text { The desire to } \\
\text { preserve slavery was } \\
\text { the cause for } \\
\text { secession. Secession } \\
\text { documents for } \\
\text { several states cite } \\
\text { slavery as their } \\
\text { reason for leaving } \\
\text { the Union. The vice } \\
\text { president of the } \\
\text { Confederacy, } \\
\text { Alexander Stephens, } \\
\text { said the country was } \\
\text { founded on the } \\
\text { belief that all men } \\
\text { are not created } \\
\text { equal, but that } \\
\text { slavery is the } \\
\text { "natural and normal } \\
\text { condition" of } \\
\text { African Americans. } \\
\text { It doesn't get any } \\
\text { clearer than that. }\end{array}$ & $\begin{array}{l}\text { "Silent Sam } \\
\text { represents the } \\
\text { heroic and brave } \\
\text { soldiers that fought } \\
\text { in the War of } \\
\text { Yankee } \\
\text { Aggression, the } \\
\text { war was Not } \\
\text { fought over } \\
\text { slavery ..." }\end{array}$ & 3 \\
\hline $\begin{array}{l}\text { It's heritage } \\
\text { not hate. }\end{array}$ & $\begin{array}{l}\text { The "heritage, not } \\
\text { hate" argument } \\
\text { ignores the near- } \\
\text { universal heritage of } \\
\text { African Americans } \\
\text { who were enslaved }\end{array}$ & $\begin{array}{l}\text { "It's history } \\
\text { period, and it's } \\
\text { also heritage not } \\
\text { hate." }\end{array}$ & 1 \\
\hline
\end{tabular}


by the millions in the

South and later

subjected to brutal

oppression under the

white supremacist

regime of Jim Crow.

Our democracy is

based on equality

under the law, and

public entities

should not

prominently display

symbols that

undermine that

concept and alienate

an entire segment of

the population.

Slaves fought

For most of the war,

the Confederacy did

for the not allow enslaved

Confederacy,

men to serve. It

which proves

changed its policy

the Civil War

only in the final

wasn't about

weeks of the war -

slavery.

a time when it

desperately needed

men. Few joined

voluntarily.

Lee, the body

servant of the

Honorable General

Robert E. Lee ...

built churches

across the North

and South and the

first credit union in

the country

designed to help

the freed blacks

and told his

people, 'Buy some

land, get yourself

educated, keep

your faith in our

Lord and Master

Jesus Christ, and

beyond all else,

put your trust only

in the Southern

white man.""

Individual citizens

still have the right to

We shouldn't

remove

fly a Confederate

things just

because

flag - even if it

offends people. That

is their First

someone may

be offended.

What about

the First

Amendment's

Amendment right.

But our government,

which is supposed to

serve all citizens,

guarantee of

freedom of

expression?

What else

would be

removed?

shouldn't endorse a

symbol that

represents the

oppression of a

group of its citizens.

This is not a

freedom-of-

expression issue.

"They died for that opinion and for that they deserve a monument to their bravery in the face armed soldiers ...

Silent Sam

represented those

that, to some

extent, wanted to

keep slavery, and

the Kent State

memorial

represents those

that caused people

to become slaves!

What is the

difference in these two groups?"

\section{OTHER:}

Restore it,

treat it with

respect, leave

it alone

"Save the

monuments. Raise

a flag every time a

monument is

destroyed."

"Leave Silent Sam

alone, it's a sad

day in America

when people can

attack and

vandalize a 


\begin{tabular}{|c|c|c|}
\hline & $\begin{array}{l}\text { Confederate } \\
\text { Monument and try } \\
\text { to justify it." } \\
\text { "Restore Silent } \\
\text { Sam Monument" }\end{array}$ & \\
\hline $\begin{array}{l}\text { OTHER: } \\
\text { Leave }\end{array}$ & $\begin{array}{l}\text { "To me this is my } \\
\text { state. And all you } \\
\text { people comes from } \\
\text { other states. If you } \\
\text { don't like it go } \\
\text { somewhere else. } \\
\text { We don't need you } \\
\text { here. if not close } \\
\text { the college down } \\
\text { for not standing for } \\
\text { the history of this } \\
\text { state." }\end{array}$ & 2 \\
\hline $\begin{array}{l}\text { OTHER: } \\
\text { One-off } \\
\text { comments, } \\
\text { unrelated } \\
\text { content, and } \\
\text { posts with no } \\
\text { text. }\end{array}$ & $\begin{array}{l}\text { "It Sounds like a } \\
\text { cool statue" } \\
\text { "Facebook forced } \\
\text { me to write a } \\
\text { review before I } \\
\text { could give the } \\
\text { statue five stars" }\end{array}$ & 7 \\
\hline
\end{tabular}

\section{Appendix B: Facebook screenshots}

\begin{tabular}{|l|l|l|l|}
\hline Sonnect with friends and the & Sign Up \\
\hline \\
World around you on Facebook.
\end{tabular}

Figure B1: Required gender selection at sign-up (Facebook, n.d.-a). 


\section{Add some common interests that your customers share.}

This will help Facebook create a better audience for your ads. You can add categories like interests, hobbies and activities.

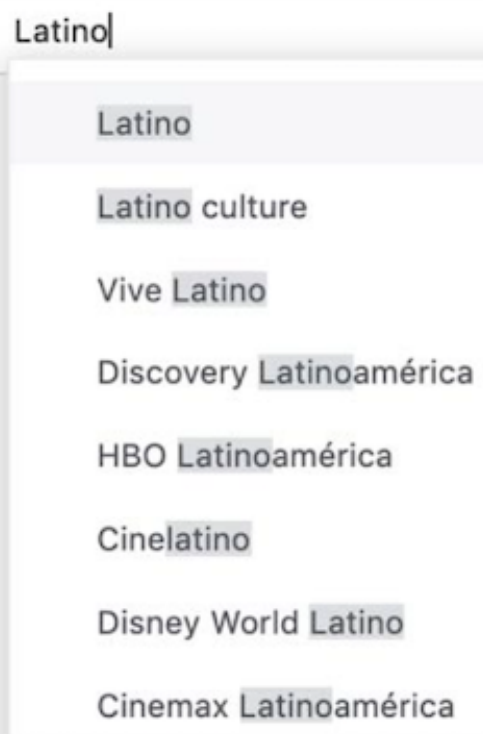

Figure B2: Latino targeted ad proxies (Facebook, n.d.-c).

\section{Add some common interests that your customers share.}

This will help Facebook create a better audience for your ads. You can add categories like interests, hobbies and activities.

Asian

Member states of the Association of Southeast Asi...

South Asian Association for Regional Cooperation

Asian american culture

Asianet

Asian cuisine

South Asian cuisine

AFC Asian Cup

Asiana Airlines

Figure B3: Asian American targeted ad proxies (Facebook, n.d.-d). 


\section{Add some common interests that your customers share.}

This will help Facebook create a better audience for your ads. You can add categories

like interests, hobbies and activities.

\section{African}

African-American music

African-American culture

African Union

Economic Community of West African States

African National Congress

Southern African Development Community

Confederation of African Football

Pan-Africanism

Figure B4: African-American targeted ad proxies (Facebook, n.d.-e).

Appendix C

\begin{tabular}{|c|c|c|c|}
\hline Act label & Description/Explanation & $\begin{array}{l}\text { Example } \\
\text { from data }\end{array}$ & $\begin{array}{c}\text { Total } \\
\text { frequency }\end{array}$ \\
\hline INFORM & $\begin{array}{l}\text { Provide "factual" } \\
\text { information; verifiable in } \\
\text { principle, even if untrue }\end{array}$ & $\begin{array}{l}\text { "287 UNC } \\
\text { alumni lost } \\
\text { their lives in } \\
\text { the civil war." }\end{array}$ & 16 \\
\hline DIRECT & Attempt to cause action & $\begin{array}{l}\text { "Put the } \\
\text { Statue back } \\
\text { up!!!!" }\end{array}$ & 9 \\
\hline CLAIM & $\begin{array}{l}\text { Make a subjective } \\
\text { assertion; unverifiable in } \\
\text { principle }\end{array}$ & $\begin{array}{l}\text { "It's a piece } \\
\text { of garbage ... } \\
\text { worthless } \\
\text { trash that } \\
\text { doesn't } \\
\text { belong ... } \\
\text { never did } \\
\text { belong ..." }\end{array}$ & 5 \\
\hline DESIRE & $\begin{array}{l}\text { A cover term including } \\
\text { three categories of irrealis } \\
\text { situation }\end{array}$ & \begin{tabular}{|l} 
"What think \\
need to \\
happen send \\
silent sam \\
was brought
\end{tabular} & 3 \\
\hline
\end{tabular}




\begin{tabular}{|c|c|c|c|}
\hline & & $\begin{array}{l}\text { down tonight } \\
8-20-18 \text { that } \\
\text { everybody } \\
\text { who had any } \\
\text { part an it } \\
\text { should be put } \\
\text { in jail and } \\
\text { made to pay a } \\
\text { big find not a } \\
\text { slap on the } \\
\text { wrist like the } \\
\text { people in } \\
\text { Durham got." }\end{array}$ & \\
\hline REQUEST & Seek action politely & $\begin{array}{l}\text { "be a lot less } \\
\text { racist please" }\end{array}$ & 2 \\
\hline REACT & $\begin{array}{l}\text { Show listenership, } \\
\text { engagement - positive, } \\
\text { negative, or neutral }\end{array}$ & \begin{tabular}{|l||} 
"it's \\
ridiculous that \\
these little \\
snowflakes \\
are trying to \\
erase history!! \\
good or \\
bad!!!"
\end{tabular} & 2 \\
\hline INQUIRE & Seek information & $\begin{array}{l}\text { "Why does } \\
\text { there need to } \\
\text { be a symbol } \\
\text { of white } \\
\text { supremacy on } \\
\text { public land? } \\
\text { Good } \\
\text { question! It } \\
\text { needs to go!" }\end{array}$ & 1 \\
\hline ELABORATE & $\begin{array}{l}\text { Paraphrase a previous } \\
\text { utterance (usually one's } \\
\text { own) }\end{array}$ & \begin{tabular}{|l|} 
"Facebook \\
forced me to \\
write a review \\
before I could \\
give the \\
statue five \\
stars, stop \\
forcing me to \\
do things \\
facebook" \\
\end{tabular} & 1 \\
\hline REJECT & $\begin{array}{l}\text { Disagree, dispute, and/or } \\
\text { challenge }\end{array}$ & $\begin{array}{l}\text { "I'm } \\
\text { incredibly } \\
\text { happy to see } \\
\text { this hateful } \\
\text { monument } \\
\text { destroyed. } \\
\text { May the } \\
\text { creators burn } \\
\text { in 'hell' } \\
\text { forever." }\end{array}$ & 1 \\
\hline
\end{tabular}

\section{Editorial history}

Received 26 July 2019; revised 6 September 2020; accepted 6 September 2020.

\section{(cc) EY-NO}

This work is licensed under a Creative Commons Attribution-NonCommercial 4.0 International License.

Rebel reviewers: Social media review pages as sites of Confederate memorial discourses by Laura March.

First Monday, Volume 25, Number 12 - 7 December 2020

https://journals.uic.edu/ojs/index.php/fm/article/download/10221/10013

doi: https://dx.doi.org/10.5210/fm.v25i12.10221 